\title{
Architectural Education in the Current of Deep Ecology and Sustainability
}

\author{
Ewa Cisek and Anna Jaglarz *(D) \\ Faculty of Architecture, Wrocław University of Science and Technology, ul. Bolesława Prusa 53/55, \\ 50-317 Wrocław, Poland; ewa.cisek@pwr.edu.pl \\ * Correspondence: anna.jaglarz@pwr.edu.pl
}

Citation: Cisek, E.; Jaglarz, A. Architectural Education in the Current of Deep Ecology and Sustainability. Buildings 2021, 11, 358 . https://doi.org/10.3390/ buildings 11080358

Academic Editor:

Derek Clements-Croome

Received: 15 July 2021

Accepted: 13 August 2021

Published: 17 August 2021

Publisher's Note: MDPI stays neutral with regard to jurisdictional claims in published maps and institutional affiliations.

Copyright: (c) 2021 by the authors. Licensee MDPI, Basel, Switzerland. This article is an open access article distributed under the terms and conditions of the Creative Commons Attribution (CC BY) license (https:/ / creativecommons.org/licenses/by/ $4.0 /)$.

\begin{abstract}
As a result of the experience and scientific research of the authors on the deep ecology and sustainability process, academic courses were created that are run at two stages of educating architecture students. The authors aimed at demonstrating the effectiveness and quality of the courses as well as the rationality of the assumptions and educational methods adopted for their implementation. One of them was the survey method, as a didactic and scientific experiment and didactic tool. The innovative educational methodology presented in the work may be implemented by other educators at architectural universities in order to improve the quality of teaching design in the spirit of pro-ecological and sustainable development. The result is a long-term action which constitutes a tool to combat the ecological crisis. It consists of bottom-up activities, both in the open landscape (ecovillages) and in the urban context (housing complexes with elements of urban farms and environmental education parks). This is connected with the application of the educational system from the pre-school level in the place of residence up to in-depth academic education.
\end{abstract}

Keywords: architectural design; interior design; architectural education; design education; deep ecology; sustainability; education method; survey method

\section{Introduction}

The article discusses the methodology of introducing issues and concepts based on deep ecology and green architecture in the courses:

- Habitats - the context of place.

- Architecture design. Research and design studio: Environmentally-friendly dwelling architecture.

- Interior design.

The above courses are conducted by the authors for 1st and 2nd degree students at the Faculty of Architecture of Wrocław University of Science and Technology. In particular, the objectives, methodology, and assumptions of these courses are extensively explained and discussed, indicating their origin and architectural practices significant for their evolution.

Our work relates to the study presented in the article entitled Assessing the impact of a program designed to develop sustainability leadership amongst staff members in higher education institutes: a case study from a community of practice perspective published in Environmental Education Research in 2018 [1]. The study focuses on the Sustainable Leadership Development Program (SLDP) that supports employees as leaders to encourage sustainable development practices within Institution of Higher Education (IHE).

This study highlighted the impact of education for sustainability programs on the professional development of university staff, including academic teachers, both at the individual and institutional levels as leaders in sustainable development. It also suggested ways to increase environmental awareness and the level of employee involvement in the Education For Sustainability (EFS) discourse in these institutions [1].

The importance of higher education institutions as leaders and role models for sustainable development in society has gained increasing recognition in recent years. However, 
despite international calls for the inclusion of education for sustainability in academic curricula, the principles of education for sustainability are still far from being integrated into the day-to-day practices of academic staff, as well as with existing compulsory curricula and educational methods [1].

One of the main reasons for this unfavorable situation is the ambiguity, multidimensionality, and complexity of the concept of sustainable development, which makes it difficult for research and teaching units to develop methods of implementing sustainable development in practice and to educate students for sustainable development. Another major barrier is the scarcity of programs and opportunities for academic teachers to develop in the field of sustainable development [1].

The growing concern for progress towards more sustainable development in architecture poses a serious challenge to both education and research. The required approach is insufficiently visible in interdisciplinary, multidisciplinary, and transdisciplinary research and pedagogy. Significant institutional and intellectual barriers to the development of integrated systems thinking remain a major concern in both research and education. Some questions arise: How can multidisciplinary and transdisciplinary research and education coexist and develop in a meaningful way in today's university structures? How can difficulties in combining the necessary teaching and research be overcome? It seems that without clear, strong, continuous leadership, as well as support, motivation, and rewards for effectively combining "two paths" in academic institutions, development in both science and education will be slow [2].

Sustainability has been identified as a significant issue in architectural design due to the extensive resources needed to make the projects a reality. Architects are responsible for contributing to the protection, preservation, and restoration of the global ecosystem. Sustainable design processes refer to activities that minimize the impact on the natural environment and create healthy living conditions. Attempts at solving environmental problems resulting from the consumerism of societies are undertaken as part of design education at universities of architecture. Courses to prepare students for eco-design in the spirit of sustainable development are becoming more common. However, it turns out that education in this field requires development and changes. Despite the fact that education in ecological and sustainable design is now considered the focus point of many educational programs, design responsibility issues are not treated with the same attention as environmental knowledge. Providing architecture students with only the necessary knowledge and skills in the field of environmental protection is not sufficient preparation for sustainable design. Among the basic features that students of architecture should learn are the sense of responsibility for the design and the ability to convince other designers, contractors, investors, developers, clients, and users to support sustainable design. The term "sustainable" seems to be accurate in relation to design solutions, while the term "responsible" is rather treated as a designer's characteristic. The "designer responsible for the project" should predict the environmental effects of the design, but also its other results, including social and environmental. Introducing students to the principles of ecological design is not enough to convince them of the validity of the idea of sustainable development in architecture and encourage them to implement it in practice [3].

A clear trend in sustainable design education is the shift from fragmentary knowledge to integrative systems that promote interdisciplinary activities. Education in the field of sustainable design in architecture has to apply a holistic approach, taking into account various aspects and conditions. With the awareness that the world is constantly changing and developing, architects should create designs that meet current needs, taking into account future requirements and evolving expectations. Design aims to ensure human health, safety, and well-being, so it is important for students to understand how architecture affects users, as well as society and the environment as a whole. The importance of education in the field of architectural design is invaluable as it develops the sensitivity, knowledge, and design skills of students as architects of the future. The task of academic teachers is to familiarize and train students in how to create sustainable architecture 
through in-depth observation, analysis, and understanding of the current environment. It is important to encourage and motivate architecture students to take a more comprehensive standpoint on "green architecture" and sustainable ecological design that uses inter-, multi-, and transdisciplinary approaches $[2,3]$.

Therefore, the knowledge and practice in this area becomes so important, both at the pre-school level, educating children in their place of residence, and finally at the academic level-identifying problems and taking actions to eliminate disturbances of the ecosystem at its source by means of implementing remedial actions with a long-term beneficial impact on the environment. Deep ecology is a kind of philosophy of life as well as a long-term movement describing the approach to the ecological crisis. It shows the reasons of the problem and suggests appropriate educational and practical activities. As a philosophy of life, it appeared in Norway at the turn of the 1970s. [4-9]. The methodology of the research conducted by the authors was based directly on the deep ecological attitude towards nature, which is favored and recommended by the Norwegian ecologist as a starting point for creative searches and, as a result, for ecological successes in environmental design. The strategies that have been applied in the education of students are based on two fundamental principles of deep ecology:

- Bioregional development, defined as development based on place. This principle is related to bottom-up activities carried out in local ecosystems. Ultimately, these actions have an impact on the long-term global effect.

- The Norwegian friluftsliv principle, created by Arne Næss, the initiator of the philosophy of deep ecology, is defined as the joy of identification with wildlife. This principle was creatively developed by Nils Faarlund into the idea of introducing wild ecosystems to cities in the form of forest and park greenery-Ecological Education Parks and creating green eco-architecture on the outskirts of cities. New ecostructures can provide direct contact with wildlife and ecological education for city dwellers without leaving their place of residence. They also shape a zone with a new spatial organization and a different audiosphere that fits into the sound ecology [4-9].

Moreover, the methodology of the research conducted by the authors was based on contemporary concepts of sustainable development and ethics of responsibility. Sustainable development should not be viewed as a fashion, necessity, and complication, but rather as an opportunity to anticipate and prepare for the future. The awareness of the need to respect and protect lasting values as well as the will to act in a sustainable way and to engage in practical, rational contribution to sustainable environmental development gives a sense of responsibility for the lives of future generations $[10,11]$. The ethics of responsibility of the German philosopher Hans Jonas is most often treated as consistent with the ethics of sustainable development. Technological progress has increased the reach of human activity to such an extent that it requires a new philosophy of responsibility in the approach to dealing with new technologies, and above all, "disruptive innovations". He formulated the ecological imperative "Act so that the effects of your action are compatible with the permanence of genuine human life" ("Act not destructively for future generations and the totality of their life conditions")-Be aware of the responsibility for the consequences of their own actions [12]. In this sense, the understanding of sustainable development is about being able to rationally meet the needs of the present and at the same time maintain a healthy, safe, and ready-to-exist environment for future generations. In architecture, as in other areas of our life, sustainable development is not only ecology, but also social, economic, psychological, and cultural factors that determine the health, safety, comfort, and social interaction of individual users. Sustainable development implies a holistic view of the ecological, economic, and social impact of technology and the material environment on humans and nature $[10,11,13,14]$. Designing ecological and sustainable architecture includes holistic, multi-directional activities ensuring optimal use conditions, including health, hygienic, and aesthetic conditions, with minimal interference in the natural environment and low consumption of natural resources. The main goal of sustainable design is to maintain harmonious relations in the system: user-building-natural environment. 
The basic characteristics of "green buildings" and their eco-equipment are functionality, efficiency, and environmentally-friendly operation and processes, including rational and effective management of water, energy, and materials [15].

Sustainable development in architecture concerns the materials, devices, installations, and equipment used in buildings, their sustainable design, construction, and production methods that enable their sustainable use. It means:

- taking into account the shape, orientation, and surroundings of the building in the design $[13,16-18]$,

- the use of an optimal body of the building $[17,18]$,

- the use of a light, effective structure [13],

- ensuring ease of fitting and assembly of building elements [10],

- introducing modularity, mobility, flexibility, transformability of individual elements of the facility $[10,15,19,20]$,

- the use of high-quality materials [10,14],

- the application of biophilic solutions $[15,21]$,

- the use of natural, minimally processed materials [15,22,23],

- taking into account the environmentally-friendly production of materials [10,14],

- the use of local materials to reduce transport costs [10,14],

- the use of recycled materials $[14,15,20,24]$,

- the use of reusable materials $[15,20,24]$,

- the use of technologies that allow for the rational and economical use of natural resources $[10,13,15,19]$,

- using solutions that ensure the health, safety, and well-being of users $[10,11,15,19,21,22]$,

- minimizing energy consumption and emission [13,25],

- the use of energy-saving and water-saving solutions [10,13,15,19,25],

- the possibility of development, transformation, and adaptability of architecture to the changing needs of users $[10,13,15,19,20]$,

- the possibility of easy disassembly and reuse of parts and elements of the building [20,24],

- taking into account the entire life cycle of the building, all phases of its existence-from design to possible demolition of the building and recycling of materials [24,25],

- taking into account the impact of the building on the environment at every stage of its construction and operation [11,13,24,25],

- the use of materials with zero and reduced carbon footprint, carbon-negative materials [26],

- taking into account the circular economy in architecture and construction-an economy model that already at the stage of assumptions and design provides for the circulation of materials: biological, designed so that their waste can be safely reintroduced into the biosphere; technical materials intended for marketing in high quality and processed so as not to harm nature [27],

- the use of high-quality durable solutions that will last for a long time in good condition $[10,14,20]$,

- the use of proven, timeless solutions [10,14,20],

- $\quad$ ensuring the possibility of uncomplicated maintenance of the building in good operational and aesthetic condition, without the need for frequent repairs and changes [10,11,13,14].

The constant search for optimal solutions to balance architecture and nature turns out not to be a matter of coincidence. This is determined in advance, right from the start, at the planning stage [10].

\section{Aims and Scope}

The article presents the methodology and methods of implementing the assumptions of deep ecology and sustainability in practice in academic teaching as part of the courses:

- Habitats - the context of place.

- Architecture design. Research and design studio: Environmentally-friendly dwelling architecture.

- Interior design. 
The above courses are conducted by the authors for 1st and 2nd degree students at the Faculty of Architecture of Wrocław University of Science and Technology. The aim of this education is to show that a deeply ecological attitude seems to be a means of identifying the reasons and eliminating the ecological crisis. The paper indicates the following educational principles and methods, developed on the basis of the theoretical and practical knowledge of the authors in the field of architectural design and their teaching and research experience:

- Educational method of four-stage work on the ecological design concept.

- The principles of shaping environmentally-friendly architecture.

- The method of assessing effectiveness and purposefulness of the research on the deep ecology process within the subject courses.

- The survey method as a didactic and scientific experiment and didactic tool.

The main purpose of the article is to show how the courses conducted by the author at two different consecutive stages of educating students (stage I: Habitats-the context of place, stage II: Architecture design. Research and design studio: Environmentally-friendly dwelling architecture and Interior design, being an element of the education of architectural engineers, were created as a result of scientific research on the deep ecology and sustainability process.

Another goal which was set by the authors was to demonstrate the effectiveness and quality of the courses and the rationality of the assumptions adopted for their implementation, which are a creative development of the fundamental assumptions of deep ecology: development based on place, and friluftsliv - the Norwegian tradition of identification with wild nature, which has evolved into the idea of introducing forest and park areas into cities as wild ecosystems and environmental education through practice.

Research on the purposefulness and legitimacy of the adopted rules for conducting the presented courses was developed during two consecutive semesters in the following academic years: 2019/2020 and 2020/2021.

\section{Innovative Research Methods}

Research into deep ecology covered the issues which were connected with the development of eco-housing complexes on the basis of the environmental and cultural context of the place, with an emphasis on interdisciplinary pre-design studies on the localization of developed topics. They constitute an extension of the three of the basic principles of deep ecology, defined as: development based on the place, friluftsliv, and environmental education through practice. The method consisted of the appropriate and careful selection of the location of areas covered by the development prepared by students, mainly in terms of the vicinity of forest and park areas intended for transformation into Ecological Education Parks and the possibility of deliberate adaptation of adjacent building plots for functions accompanying residential areas, such as forest kindergartens, eco-educational sensory pavilions, ecological education centers, recycling centers, and urban crops with street food. An analysis of the resulting concepts was applied. Then, a selection of the issues, which served as the fundamental basis for both courses, was subjected to a critical analysis. The courses were created by the method of synthesizing elements which proved successful in practice and contributed to the effectiveness of the entire process. The following aspects were tested successively:

- The frequency and legitimacy of the selection of the area covered by the study, depending on the vicinity of forest and park areas and the classification of the selected area, respectively: to the suburban or strictly urban zone (Method of analysis and synthesis).

- The legitimacy of the experimental introduction of an additional innovative method of interdisciplinary research at the 2nd degree. (These were the studies of soundscape of places covered by the study to honor the ecology of sound as a significant part of the deep ecology process).

- Purposefulness and effectiveness of interdisciplinary issues introduced into the educational process, through adequately distributed control enclosure tasks performed by students during properly distributed time (Method of analysis and synthesis and In Situ Method implemented in the form of: drawing presentations of an interdisciplinary 
topic and practical tasks-environmental education through practice-revitalization of public spaces within the Campus of the Faculty of Architecture of the Wrocław University of Science and Technology, e.g., box-type permaculture crops composed by students and combined with campus spaces requiring revitalization).

- The effectiveness of the use of computer support in the field of energy efficiency simulations of designed layouts, and finally the energy balance of objects, which makes up the entire spatial composition of the study (Method of analysis-Life Cycle Assessment /LCA of buildings and carbon footprint calculation).

- The frequency and effectiveness of students choosing a profile of topics within the scope of deep ecology. The Survey Method conducted among students (Interior design) was aimed at recognizing the general knowledge, awareness, and experiences of students connected with the topic of "green architecture", as well as examining the impact of the courses and the discussed problems on the development of their interest in the issues of ecological design.

\section{Deep Ecology in Architectural Education}

Næss' papers on deep ecology became an inspiration in architectural education. They also became the basis for research on the methodology of subject courses, setting out directions and research areas implied locally, which were closely connected with the global mainstream. However, necessary and significant changes are only possible when long-term strategies, which harmonize with nature and do not compete or fight with it, are developed. One of these strategies, which was already practiced locally in Norway by ecologist Per Ingvar Haukeland, was researched as part of the author's two subject courses. It is defined as "development based on place", which is closely connected with the renewal of the sense of place. In the context of spatial planning, it boils down to bottom-up activities, focusing on a small piece of space and trying to make remedial actions within a given area, local ecosystem, where we live and work, as well as where fundamental changes should be introduced. Following Haukeland's thought, who proposes to act according to the following principle- "We should start from the point where we are and go towards the point where we will see that our vital needs are met" [28] —as a result of the analyses and syntheses conducted within the framework of the research, the conclusions, which contributed to the creation of the presented courses, were drawn as follows:

- Exploring how a place where social development is being tried in harmony with nature is related to what we call an ecoregion (bioregion), a natural region.

- Application of place-based economics, the natural consequence of which will be local food production based on the philosophy of permaculture, diversity, and complementarity of the local ecosystem.

- Skillful application of technologies which are oriented towards deeply rooted values.

These actions may concern both rural and urban areas.

Ecovillages are built in the open landscape. Residential buildings, together with adjacent greenhouses, gardens, henhouses, orchards, ecological crops, pastures, as well as production and wild forests create complementary and self-sufficient eco-structures. In Norway, the whole series of such projects has been launched in recent years. The most significant are the ecovillage of Hurdal-HØL in Hurdalsenteret (implementation in 2014) as well as Grenda and Åsa in Ringerike (implementation in 2016), [29]. In the rural environment, a place-based development may also apply to activities in small groups, i.e., family and neighbors, focusing on introducing ecological solutions in these small communities, which consist in planning and using land, local green products, environmental education, e.g., by means of rural tourism or training and ecological agriculture activities [30]. In recent years, a number of ecovillages have been established throughout Poland to promote ecological education and self-sufficiency based on permaculture.

In the urban context, planning activities oscillating around Næss' thought are recently implemented projects in the field of: 
- Housing complexes maintained in the spirit of deep ecology with designed elements of a city farm (horizontal or vertical) with a focus on the following objectives: educational and local production of food/green products which meet the needs of residents (which supports self-sufficiency). They combine the reproduction of traditional landscape elements such as woodlands, balks, meadows, and pastures, small water reservoirs with exhibition and educational functions and small gastronomy, focused on the promotion of local products produced on the spot. Organic farming is based on biodiversity and permaculture. A return to grazing livestock in cities, for example goats and sheep, even for short periods, makes it possible to maintain the biodiversity of semi-natural areas and to expose valuable views.

- Implementing the principle friluftsliv, which is part of Næss' philosophy of life, designed green, wild areas in a city, increasing the offer of environmental education and protecting local biodiversity and integrating the communities living in their surroundings around these activities. The following elements become important in designing such new models of ecological education parks:

- diversity of design solutions, participation of semi-natural vegetation, limitation of care treatments, emphasis on education,

- $\quad$ sequence of views, landscapes, and impressions, which is formed by the mosaic layouts of habitats,

- viewpoints (beauty spots) which enable observation of nature from different perspectives,

- $\quad$ using ecological succession as a creator of modern parks or its parts.

The aim is to increase the local biodiversity by modeling succession processes and the mosaic character of plant communities. Users gain knowledge about the processes taking place, e.g., cycles in nature or ecological succession, and they can, for example, see how the vegetation changed over a period of about 10 years in the photographs [31].

A model example of green eco-architecture integrated with an ecological education park is Nansen Park on the Fornebu peninsula in Norway, created on the revitalized area of the former airport [29]. Central European examples include the development of a part of the Belgian Hobokense Polder into an ecological education park with a green housing complex called Groen Zuid in Antwerp, and Nordbahnhof Park in Germany [31].

A key task for organizations dealing with nature conservation in Poland are activities for the development of green areas in cities and their adaptation for educational purposes. At the same time, they constitute new green jobs for field educators and local leaders. Raising the standard of visiting environmentally valuable areas in cities constitutes an opportunity to attract more people interested in nature conservation and change their lifestyles to those in line with the principles of deep ecology, thus encouraging them to spend more time there. The message about the species occurring in a given place and natural processes taking place, as well as about the benefits offered by urban ecosystems to all forms of life inhabiting them without exception, is very important for local communities. Appropriately designed infrastructure in such places should minimize the impact of visitors on the ground within the area with strict protection, whereas locating environmental education centers on its outskirts will contribute to the implementation of facilities using modern and nature-friendly technologies. Tomasz Molenda, speaking to problems around the protection of anthropogenic environments in Poland, believes that damages to the natural environment resulting from urbanization processes are highly irreversible and costly if the aim is to restore a state close to the natural one. On the other hand, many researchers point to the ecological importance of the transformed natural systems and urban ecosystems to an extent that does not allow them to return to the historical state of the past. In literature, they are referred to as novel ecosystems, and in relation to cities, urban novel ecosystems. Despite the changed species composition along with the participation of native and alien species evolving without active human participation, they offer many benefits and constitute a new value [32]. Elements of urban agriculture based on permaculture and environmentally-friendly technologies integrated with housing 
architecture, which are successively introduced in academic education, are part of the long-term deep ecology movement as bottom-up activities influencing the global state of the natural environment in the long run.

It is particularly important to implement the analyzed subjects of ecological education through practice, e.g., permaculture crops composed by students as pocket gardens and a means of revitalizing urban space into educational programs.

The presented conclusions, which are the result of analysis and synthesis achieved in the course of the research, led to the creation of the presented courses. It is recommended that other educators use the guidelines developed by the authors.

\section{Deep Ecology and Sustainability in Student Architectural Design}

At present, Næss' philosophy of life of deep ecology is developed as part of the subject: Habitats - the context of a place for the 1st degree studies at the Faculty of Architecture of Wrocław University of Science and Technology, with continuation of the 2nd degree studies during a selectable subject under the following name: Architecture design. Research and design studio: Environmentally-friendly dwelling architecture and in the subject Interior design.

The courses are addressed to 1st and 2nd degree students who differ in the degree of experience and detailed knowledge in the field of ecological architecture. Therefore, the organization of these classes and the scope of the development of topics are varied. Stage I emphasizes one of the fundamental principles of deep ecology-bioregional development. Development based on place is intended to show the importance of bottom-up actions that ultimately influence global strategies, and to show how people, culture, and nature co-evolve over time. It is reasonable to determine the environmental potential of the area covered by the study in terms of the organization of the city farm. The measure aims to ensure self-sufficiency in terms of food production and renewable energy for the shaped architectural structures. These studies are combined with the activities of students in the field of detailed analyzes of the area and variant development of the concept in terms of the organization of spatial and social structures, supporting the self-sufficiency of housing complexes such as: cohousing, coliving, and cooperatives. Work on the design concept is carried out in groups of two students. Stage II additionally stresses the second fundamental principle of deep ecology, friluftsliv, as finding joy in identification with wildlife. Residential complexes are designed on the border with forest and park areas transformed into wild ecosystems that evolve without human participation, the so-called ecological education parks. The activities of students focus on shaping green architecture in constant interaction with wild ecosystems of parks in an open suburban landscape in the form of an ecovillage or in strictly urban landscape as green responsive architecture. The residential functions are supplemented with service, recreational, and educational functions, such as: forest kindergartens, interactive pavilions, acoustic capsules, and eco-educational bird watching towers. As part of detailing the concept, additional ecological elements are also designed. Examples are nesting boxes for birds integrated in harmony with the architecture, home composters, and permaculture boxes. The education of students also includes learning in the field of calculating the energy efficiency of buildings and the carbon footprint and estimating the size of rainwater tanks. These residential eco-structures are aimed at two important goals, i.e., educational — connected with the environmental education of users from the youngest to seniors and universal design [32], as well as agrarian-local food production based on permaculture with the possibility of breeding and grazing animals or other activities such as the organization of apiaries for bees. The studies include urban and architectural scales. Work on the design concept is carried out in groups of three students. In their basic assumption, they implement the attitude of being in the world by perceiving nature, culture, and the self as a combined whole, in accordance with the principle-placebased development. The context of a place becomes the key to the idea of foundation. First of all, the environmental and natural contexts are taken into account and then the cultural context. These assumptions are in most cases of an application nature and fit into the urban novel ecosystems trend. These projects, both in terms of ideas and implementation, are 
an attempt at responding to the deepening climate and ecological crises. The work on the design concept: Habitats - the context of a place (2019/2020), Architecture design. Research and design studio: Environmentally-friendly dwelling architecture (2020/2021) was divided into several stages, which were evaluated (Table 1).

Table 1. Evaluation of the stages of work on design concept.

\begin{tabular}{|c|c|c|c|c|}
\hline Stage & $\begin{array}{l}\text { The Scope and Method of } \\
\text { Works Performed }\end{array}$ & $\begin{array}{l}\text { Organization } \\
\text { of Work }\end{array}$ & $\begin{array}{l}\text { Type of Drawings } \\
\text { Performed }\end{array}$ & $\begin{array}{l}\text { Subject and Purposefulness of the } \\
\text { Research on the Deep Ecology } \\
\text { Process, Method }\end{array}$ \\
\hline Stage I & $\begin{array}{l}\text { Analytical and research, part I, includes } \\
\text { environmental and natural analyses of the } \\
\text { area covered by the study with an attempt } \\
\text { at determining the way this place is } \\
\text { connected with a bioregion, a natural } \\
\text { region. These activities are combined with } \\
\text { an in-depth inventory of the area, } \\
\text { collection of photographic documentation, } \\
\text { preparation of maps of the area analyses in } \\
\text { terms of plant species present there, } \\
\text { topography, the presence of watercourses } \\
\text { or water reservoirs, existing pedestrian and } \\
\text { road transport, the character of the } \\
\text { building development surrounding this } \\
\text { area, and its functions. Next, the } \\
\text { environmental conditions of the place are } \\
\text { determined (1st and 2nd degree studies). } \\
\text { Acoustic analysis and audiosphere of the } \\
\text { place (analysis in terms of sound ecology), } \\
\text { analysis of insolation, and shading of } \\
\text { buildings (2nd degree studies). }\end{array}$ & $\begin{array}{l}\text { Students work in } \\
\text { groups of two } \\
\text { (1st degree } \\
\text { studies) or three } \\
\text { (2nd degree } \\
\text { studies) people } \\
\text { with a tutor. }\end{array}$ & $\begin{array}{l}\text { At this stage of work, } \\
\text { they make a model of } \\
\text { the area covered by } \\
\text { the study on a scale of } \\
1: 1000,1: 500 \\
\text { (1st degree studies), } \\
1: 2000,1: 1000,1: 500 \\
\text { (2nd degree studies). }\end{array}$ & $\begin{array}{l}\text { The work is of a workshop character } \\
\text { during which the collected data is } \\
\text { analyzed, then it is organized and } \\
\text { supplemented with conclusions which } \\
\text { are useful for further stages of } \\
\text { the study. } \\
\text { The following aspects were researched: } \\
\text { frequency and legitimacy of } \\
\text { selecting the area covered by the } \\
\text { study, depending on the vicinity } \\
\text { of forest and park areas and the } \\
\text { classification of the selected area, } \\
\text { respectively: to the suburban or } \\
\text { strictly urban zone (1st and 2nd } \\
\text { degree studies), Analysis and } \\
\text { synthesis method. }\end{array}$ \\
\hline Stage II & $\begin{array}{l}\text { Analytical and research, part II, it is a } \\
\text { literature study. Searching for inspiration } \\
\text { from various, often interdisciplinary fields, } \\
\text { including, among other things, architecture, } \\
\text { fine arts, eco-philosophy, and natural } \\
\text { sciences. Analysis of the typology of social } \\
\text { organization of housing structures such as: } \\
\text { cohousing, co-living, cooperatives (1st } \\
\text { degree studies). At this stage, meetings } \\
\text { with people dealing with deeply ecological } \\
\text { issues are organized and the experience of } \\
\text { colleagues who participated in workshops } \\
\text { on ecological building technologies (e.g., } \\
\text { using hemp concrete) and the } \\
\text { accompanying ecological cultivation (e.g., } \\
\text { based on permaculture) are used (1st and } \\
\text { 2nd degree studies). } \\
\text { An additional research method In Situ } \\
\text { consists in examining the soundscape of } \\
\text { the planned investment site. }\end{array}$ & $\begin{array}{l}\text { Students work in } \\
\text { groups of two (1st } \\
\text { degree studies) or } \\
\text { three (2nd degree } \\
\text { studies) people } \\
\text { with tutor. }\end{array}$ & $\begin{array}{l}\text { At this stage, the } \\
\text { ideological model of } \\
\text { the functional and } \\
\text { spatial concepts } \\
\text { is made. }\end{array}$ & $\begin{array}{l}\text { The purpose of these activities is to } \\
\text { create the foundations for the } \\
\text { ideological board of the project. } \\
\text { The following aspects were researched: } \\
\text { Variant solutions of housing } \\
\text { complexes in terms of social } \\
\text { organization of housing } \\
\text { structures such as: cohousing, } \\
\text { co-living, cooperatives, ensuring } \\
\text { self-sufficiency of housing } \\
\text { structures (1st degree studies). } \\
\text { The legitimacy of the } \\
\text { experimental introduction of an } \\
\text { additional innovative method of } \\
\text { interdisciplinary research at the } \\
\text { 2nd degree. These were the } \\
\text { studies of soundscape of places } \\
\text { covered by the study to honor } \\
\text { the ecology of sound as a } \\
\text { significant part of the deep } \\
\text { ecology process (2nd degree } \\
\text { studies), In Situ Method. }\end{array}$ \\
\hline
\end{tabular}


Table 1. Cont.

\begin{tabular}{|c|c|c|c|c|}
\hline Stage & $\begin{array}{l}\text { The Scope and Method of } \\
\text { Works Performed }\end{array}$ & $\begin{array}{l}\text { Organization } \\
\text { of Work }\end{array}$ & $\begin{array}{l}\text { Type of Drawings } \\
\text { Performed }\end{array}$ & $\begin{array}{l}\text { Subject and Purposefulness of the } \\
\text { Research on the Deep Ecology } \\
\text { Process, Method }\end{array}$ \\
\hline Stage III & $\begin{array}{l}\text { The concept of landscape planning of the } \\
\text { area covered by the study-formation of an } \\
\text { eco-structure-a residential environment } \\
\text { integrally synchronized with the elements } \\
\text { of a city farm, i.e., horizontal or vertical, } \\
\text { wild or social gardens, apiaries and } \\
\text { meadows, giving animals the possibility to } \\
\text { graze, e.g., goats or sheep (1st and 2nd } \\
\text { degree studies) and wild } \\
\text { ecosystems-ecological education parks in } \\
\text { the suburban (ecovillages) and in strictly } \\
\text { urban zones (green responsive architecture) } \\
\text { associated with eco-services, such as forest } \\
\text { kindergartens, small gastronomy based on } \\
\text { local consumption and sales, ecological } \\
\text { products produced on site, architectural } \\
\text { elements for eco-education (2nd degree } \\
\text { studies). The overall concept takes into } \\
\text { account the principles of universal design, } \\
\text { which includes the needs of the elderly and } \\
\text { the disabled [33]. }\end{array}$ & $\begin{array}{l}\text { Students work in } \\
\text { groups of two (1st } \\
\text { degree studies) or } \\
\text { three (2nd degree } \\
\text { studies) people } \\
\text { with tutor. }\end{array}$ & $\begin{array}{l}\text { Finally, a model of the } \\
\text { entire layout is made } \\
\text { on a scale of } 1: 200 . \\
\text { There is also a } \\
\text { simulation of the } \\
\text { energy efficiency of } \\
\text { the designed spatial } \\
\text { composition with the } \\
\text { use of a computer } \\
\text { program. }\end{array}$ & $\begin{array}{l}\text { The following aspects were researched: } \\
\text { Purposefulness and effectiveness } \\
\text { of interdisciplinary issues } \\
\text { introduced into the educational } \\
\text { process, through adequately } \\
\text { distributed control enclosure } \\
\text { tasks performed by students } \\
\text { during properly distributed time } \\
\text { (1st degree studies). These tasks } \\
\text { are carried out in a drawing and } \\
\text { practical form, e.g., in the form } \\
\text { of composed box crops of } \\
\text { permaculture set on the Campus } \\
\text { of Faculty of Architecture of } \\
\text { University of Wrocław Science } \\
\text { and Technology } \\
\text { (2nd degree studies). } \\
\text { Analysis and synthesis Method. } \\
\text { In Situ Method. }\end{array}$ \\
\hline Stage IV & $\begin{array}{l}\text { Detailed solutions for the housing } \\
\text { development structure. Functional, spatial, } \\
\text { structural, technological, and material } \\
\text { solutions. Application of ecological } \\
\text { solutions in the housing complex designed } \\
\text { the development of technological schemes } \\
\text { of ecological and environmentally-friendly } \\
\text { solutions (1st and 2nd degree studies). } \\
\text { Detailed technological solutions: } \\
\text { construction details, calculating the } \\
\text { capacity of rainwater tanks, calculating the } \\
\text { energy efficiency of buildings, and the } \\
\text { carbon footprint (2nd degree studies). }\end{array}$ & $\begin{array}{l}\text { Students work in } \\
\text { groups of two (1st } \\
\text { degree studies) or } \\
\text { three (2nd degree } \\
\text { studies) people } \\
\text { with tutor. }\end{array}$ & $\begin{array}{l}\text { The work is carried } \\
\text { out with the support } \\
\text { of colleagues from } \\
\text { other industries, i.e., } \\
\text { constructors and } \\
\text { technologists. The } \\
\text { energy balance of } \\
\text { designed buildings is } \\
\text { calculated. }\end{array}$ & $\begin{array}{l}\text { The following aspects were researched: } \\
\text { - Frequency and effectiveness of } \\
\text { the students' choice of a profile } \\
\text { of topics within the scope of } \\
\text { deep ecology (1st degree } \\
\text { studies), analysis, and } \\
\text { synthesis method. } \\
\text { Life Cycle Assessment (LCA) of } \\
\text { buildings and carbon footprint } \\
\text { analysis (2nd degree studies). }\end{array}$ \\
\hline
\end{tabular}

The criteria for assessing Interior design 2019/2020 course were established on the basis of the available knowledge and previous experience in the field of "green architecture" and ecological design.

- $\quad$ Study and analysis of ecosystems, plant, and animal behaviors [34-36],

- Gaining knowledge about past experiences and current opportunities, indigenous construction methods, technologies and materials, topography, plant vegetation, light, and solar energy [36-39],

- Understanding nature and learning how to intuitively, organically, and cosmologically live according to the conditions dictated by nature [34-36].

The above actions became the basis for developing the principles of shaping environmentally-friendly architecture:

1. Nature as a source of associations and inspirations in architecture (miracles of nature, hydrological, geological, and astronomical phenomena, discoveries in biophysics and astrophysics, etc. as inspirations, imitating nature, using nature patterns and bionics-biomimicry).

2. Integration of architecture and landscape as well as combination of a building with the surrounding context.

- $\quad$ Architecture as part/extension of the landscape.

- Using elements of the natural environment so that they appear to be part of architecture.

- $\quad$ Camouflage as aesthetic sustainability [40,41].

- Compatibility of buildings and gardens. 
- $\quad$ Permeation of the inside with the outside.

- Interaction from inside to outside and vice versa.

- $\quad$ Ensuring a satisfactory view from the window.

- $\quad$ The use of forms which reflect the contours of the landscape.

- Obtaining native materials from the landscape.

3. The combination of the nature of the material, the nature of functionality, and the nature of action.

4. Connecting functionality with processes taking place in nature, similar to human behaviors:

- $\quad$ Looking for shelter and a sense of security.

- Searching for contact with nature.

- Looking for food.

- Looking for light and dark, color.

- $\quad$ Escape from the city noise.

- $\quad$ Seeking peace and balance of mind.

- $\quad$ Searching for sensations.

5. The use of symbolism connected with nature as a way of integrating architecture into the cultural and nature context.

6. Combination of nature and art.

7. Combination of environmentally-friendly technology, saving natural resources and aesthetic value.

8. Treating components of environmentally-friendly technologies as artistic matter and showing their connections with nature, life, and the symbolism of the building.

9. The use of materials which are recyclable and undergo restoration.

10. The use of energy-saving materials (production cycle-transport, processing, life cycle).

11. Harvesting indigenous materials (e.g., using native wood).

12. Storage and economical water management.

13. Low exploitation costs.

14. Re-use of existing buildings.

15. Reducing the use of chemicals which deplete ozone and affect health.

16. Efficient use of energy.

17. Passive daylight strategies [42].

18. Biodynamic lighting strategies in daylighting and tunable lighting [42,43].

19. Optimization of acoustic solutions as protection of human health and the sound landscape [44].

20. Orientation in relation to the directions of the world.

Course design topics in the scope of "green architecture":

1. Eco-style apartment.

2. Teahouse-a place for replacing plant seedlings.

3. Office as a "green oasis".

4. A shop with plants, a florist's shop with an exhibition, educational, and workshop part.

5. A place for hortitherapy (horticultural therapy).

6. Restaurant-gazebo.

7. Restaurant with an orangery, a winter garden, a green patio.

8. Restaurant with roof terrace.

\section{Features of "green architecture" and biophilic design in student projects:}

1. The use of natural, unprocessed, raw materials.

2. The use of ecological natural earth colors.

3. The use of greenery in various forms: hanging gardens, green walls, green ceilings, openwork green walls, partitions, structures integrated with plants, mobile pots, integrated and built-in pots, plant overhang systems, plant wall compositions (e.g., with irrigation systems for plants in pots), grass on the flooring, grass on tables, solutions 
combining furniture and hardware with plants, pots with plants as systems of variable interior arrangement, forests in a jar, etc.

4. Introducing the water element in the interior-water wall, pond, fountain, etc.

5. Designing green leisure zones-balcony, terrace, orangery, winter garden, atrium, patio, gazebo, etc.

6. The use of garden furniture: swings, hammocks, benches.

7. The use of organic and biomorphic forms.

8. Introduction of rock, stalagmite, and stalactite motifs.

9. Filtering light and color-variability.

10. The use of organic and plant patterns and motifs.

11. The use of a large amount of wood in the finishing of floors, walls, ceiling, casing of structural elements, openwork structures separating zones, wooden elements of equipment, wooden accents.

12. The use of recycled materials, reuse of equipment elements, giving them new functions.

13. Sunlight regulation, application of window blinds.

14. The use of bio-fireplaces.

15. The use of natural fabrics, rattan, cork, wicker, natural strings, etc.

16. The use of wallpapers based on wood pulp, hay, and wildflowers.

17. The use of ecological paints and impregnations.

18. The use of energy-saving LED lighting.

19. The use of water-saving bathroom solutions.

20. The use of acoustic solutions and materials.

21. The use of hydroponics in the interiors.

Research method used: Analysis and Synthesis Method, Survey Method conducted among students.

\section{Research Results and Discussion}

The author assessed the effectiveness and purposefulness of research on the process of deep ecology within the following subjects: Habitats - the context of the place, Architecture design. Research and design studio: Environmentally friendly dwelling architecture. The findings of the research resulting from the Analysis and Synthesis and In Situ methods were compared (Table 2).

Table 2. Assessing the effectiveness and purposefulness of the research on the deep ecology process within the subject courses: Habitats - the context of place, Architecture design. Research and design studio: Environmentally-friendly dwelling architecture (the results of the research resulting from the methods Analysis and Synthesis as well as In Situ were compared).

\begin{tabular}{|c|c|c|c|c|}
\hline $\begin{array}{l}\text { Project subject to } \\
\text { be evaluated }\end{array}$ & $\begin{array}{l}\text { Research 1: } \\
\text { The frequency and } \\
\text { legitimacy of selecting } \\
\text { the area covered by the } \\
\text { study, depending on } \\
\text { the classification of the } \\
\text { selected area according } \\
\text { to suburban or strictly } \\
\text { urban zone. } \\
\text { Method: } \\
\text { Analysis and synthesis }\end{array}$ & $\begin{array}{l}\text { Research 2: } \\
\text { Validity of the } \\
\text { experimental } \\
\text { introduction of an } \\
\text { additional, innovative } \\
\text { method of } \\
\text { interdisciplinary research } \\
\text { at the second degree. } \\
\text { These were studies of the } \\
\text { soundscape of the } \\
\text { study area. } \\
\text { Method: } \\
\text { In Situ with the use of } \\
\text { audiosphere recording } \\
\text { equipment }\end{array}$ & $\begin{array}{l}\text { Research 3: } \\
\text { Purposefulness and } \\
\text { effectiveness of } \\
\text { interdisciplinary issues } \\
\text { introduced into the } \\
\text { educational process. } \\
\text { Method: } \\
\text { Analysis and synthesis, } \\
2 \text { enclosure tasks, } \\
\text { carried out individually } \\
\text { by students, after each } \\
\text { completion of the } \\
\text { project. }\end{array}$ & $\begin{array}{l}\text { Research 4: } \\
\text { The frequency and } \\
\text { effectiveness of } \\
\text { students' choice of a } \\
\text { profile of topics within } \\
\text { the scope of deep } \\
\text { ecology. } \\
\text { Method: } \\
\text { Analyses and syntheses } \\
\text { of projects. }\end{array}$ \\
\hline
\end{tabular}


Table 2. Cont.

\begin{tabular}{|c|c|c|c|c|}
\hline $\begin{array}{l}\text { 1. Habitats-the } \\
\text { context of a place }\end{array}$ & $\begin{array}{l}\text { The research showed } \\
\text { the highest frequency } \\
\text { of the topic selection } \\
\text { and effectiveness of } \\
\text { solutions in the } \\
\text { suburban area in the } \\
\text { vicinity of forest and } \\
\text { park areas } 70 \% \text {, in the } \\
\text { strict center zone, } 30 \% \text {. }\end{array}$ & $\begin{array}{l}\text { The method was not } \\
\text { introduced. }\end{array}$ & $\begin{array}{l}\text { The research showed } \\
\text { purposefulness of } \\
\text { the method. }\end{array}$ & $\begin{array}{l}\text { The research showed } \\
\text { the greatest frequency } \\
\text { and efficiency of } \\
\text { solutions, especially in } \\
\text { the area of urban farms } \\
\text { and the organization of } \\
\text { cohousing social } \\
\text { structures }(80 \%) \text {. }\end{array}$ \\
\hline $\begin{array}{l}\text { 2. Architecture } \\
\text { design. Research and } \\
\text { design studio: } \\
\text { Environmentally- } \\
\text { friendly dwelling } \\
\text { architecture }\end{array}$ & $\begin{array}{l}\text { The research showed } \\
\text { the highest frequency } \\
\text { of topic selection and } \\
\text { effectiveness of } \\
\text { solutions in the vicinity } \\
\text { of forest and park areas } \\
\text { in the suburban area } \\
40 \% \text { and in the strict } \\
\text { center zone, in the } \\
\text { vicinity of the } \\
\text { ecological education } \\
\text { park } 60 \% \text {. }\end{array}$ & $\begin{array}{l}\text { The research proved the } \\
\text { usefulness of the method } \\
\text { in the proper selection of } \\
\text { the study site and the } \\
\text { adopted design } \\
\text { assumptions. }\end{array}$ & $\begin{array}{l}\text { The research showed } \\
\text { purposefulness of } \\
\text { the method. }\end{array}$ & $\begin{array}{l}\text { The research showed } \\
\text { the greatest frequency } \\
\text { and effectiveness of } \\
\text { solutions, especially in } \\
\text { the area of issues of } \\
\text { energy efficiency of } \\
\text { buildings }(90 \%) \text {. }\end{array}$ \\
\hline
\end{tabular}

"Green Architecture" or Ecological Design-the questionnaire for students

Taking into account the criteria adopted in order to evaluate Interior design course, the course which was conducted in the years 2019/2020 was assessed. The evaluation shows that $20 \%$ of students participating in the Interior design course 2019/2020 chose design topics in the scope of "green architecture" and applied the principles of shaping environmentally-friendly architecture and used clear elements of ecological and biophilic design in their projects.

The evaluation of the course became the basis for preparing a questionnaire-a didactic and scientific experiment aimed at increasing interest among students in the subject of "green architecture" and ecological design. The Survey Method conducted among students (Interior design) was aimed at recognizing the general knowledge, awareness, and experiences of students connected with the topic of "green architecture" as well as examining the impact of the courses and the discussed problems on the development of their interest in the issues of ecological design.

At the beginning of the design classes, presentations on contemporary trends in interior design with a clear emphasis on the principles of shaping environmentally-friendly architecture, the features of "green architecture" and biophilic design, as well as sustainable development in architecture were conducted for students. The survey was conducted among students participating in the Interior design course 2020/2021 in the middle of the semester (the course duration is 15 weeks) instead of delivering the intermediate project, which had been so far practiced within the framework of the course.

The survey method was prepared in the form of 10 questions, one of which was illustrated. The following questions were part of the questionnaire:

\section{Select the 3 criteria that you consider most important for ecological design.}

- The use of natural, unprocessed materials.

- The use of large amounts of wood.

- The use of a large amount of greens.

- $\quad$ The use of recycled materials.

- The application of technologies allowing for rational and economical use of natural resources.

- The application of solutions that ensure the health and well-being of users

- $\quad$ Another answer. 
2. Have you had the opportunity to learn about the principles of ecological design during the previous courses?

- Yes.

- No.

- Partially.

3. Have you had the opportunity to use an interior with ecological solutions?

- Yes.

- No.

- I do not know, maybe.

4. If you answered "yes" to the previous question, indicate the type of ecological interior that you used.

- Residential.

- Office.

- Gastronomic.

- Commercial.

- $\quad$ Another answer.

5. Indicate the benefit resulting from ecological design that you consider the most important.

- $\quad$ Protection of the natural environment.

- Health and well-being of users.

- Living in harmony with nature.

- Financial saving.

- Another answer.

6. In your opinion, which of the following concepts is the best example of "green architecture"?

- $\quad$ An office space with lots of plants and natural accents (e.g., birch tree trunks).

- Restaurant interior designed from recycled materials (e.g., wooden pallets).

- A house with water and energy saving solutions (e.g., solar panels).

- Another answer.

7. Do you feel encouraged to green design in the future?

- Yes.

- No.

- Partially.

8. If yes, what is special inspiration for you?

- Fashion and trends in contemporary architecture (e.g., biophilic design).

- Worldview, beliefs, lifestyle.

- Anticipation and forward thinking about future generations.

- Socio-economic and cultural development.

- Technological progress and innovation.

- Another answer.

9. Does the knowledge shared by the course instructors arouse your interest in the subject of "green architecture"?

- Yes.

- No.

- Partially.

10. In the last question with 5 examples of architecture in different ecological contexts (Table 3) the students were asked which of the images they found most inspiring to take up the topic of "green architecture" and ecological design.

Discussion of the survey results: 
How to shape the environment which was built in harmony with nature and aesthetics? The answer may be the search and determination of new directions of "green architecture", which is a combination of nature, art, and technology, as well as the creation of beautiful and friendly spaces for societies which increasingly need contact with nature.

If architecture as a shelter for humans is not detached from the broad environmental context, then designing an ecologically and socially safe future may turn out to be feasible. It is extremely important to sensitize students of architecture as future creators of our surroundings to the above-mentioned aspects. What is their knowledge, awareness, and experience connected with the topic of "green architecture"? Are the issues discussed by the lecturers and is the way of conducting classes inspiring and encouraging to ecological designing? Do they contribute to the development of students' interest in the topics of "green architecture" and biophilic design? These and other questions appeared in the questionnaire, which was one of the scientific methods applied in our research. The questionnaire was completed by 66 students-participants of the courses conducted by the authors. The following criteria were considered by students to be the most important in ecological design: the use of technologies which provide the rational and economical use of natural resources ( $87.9 \%$ of responses), the use of recycled materials ( $75.8 \%$ of responses), the use of solutions ensuring health and well-being of users (53.0\% of responses). Overall, $97.0 \%$ of the students participating in the survey admitted that they had an opportunity to learn the principles of ecological design at previous courses (37.9\% fully, 59.1\% partially). Only $52 \%$ of the respondents confirmed that they used the interior in which ecological solutions were applied. Among the functions mentioned, there appeared residential $(32.4 \%)$, gastronomic $(35.3 \%)$, commercial $(35.3 \%)$, office $(5.9 \%)$, as well as hygienic and sanitary functions (public toilet), $(2.9 \%)$. Most students (73.8\%) consider environmental protection to be the most important benefit resulting from ecological design. Other benefits include living in harmony with nature (16.9\%) and health and well-being of users (7.7\%). On the other hand, no one indicated financial savings as a benefit. The concept of a house with water and energy saving solutions was recognized as the best example of "green architecture" (75.8\% of responses). There were also responses aimed at the use of recycled materials $(19.7 \%)$. The entire group of students participating in the study felt encouraged to incorporate green design in the future ( $89.4 \%$ full and $10.6 \%$ partially). The most important inspiration turns out to be foreseeing and forward-thinking about future generations $(60.6 \%)$. Other motivations include worldview, beliefs, lifestyle $(25.8 \%)$, technological progress, and innovation (6.1\%), fashion, and trends in contemporary architecture (3.0\%). The knowledge shared by the course instructors aroused interest in the subject of "green architecture" among the majority of students ( $48.5 \%$ fully, $50.0 \%$ partially).

Encouragingly, most students consider environmental protection to be the most important benefit of green design. It is interesting that no one has indicated financial savings as a benefit, but this topic is also important-this result can be significant for improving the course and developing students' awareness in this aspect as well.

The last question contained 5 examples of architecture in different ecological contexts (Table 3). The students were asked which of the images they found most inspiring to take up the topic of "green architecture" and ecological design. 


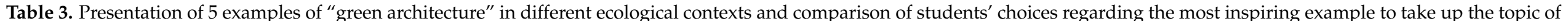
"green architecture" and ecological design (All images by Anna Jaglarz).

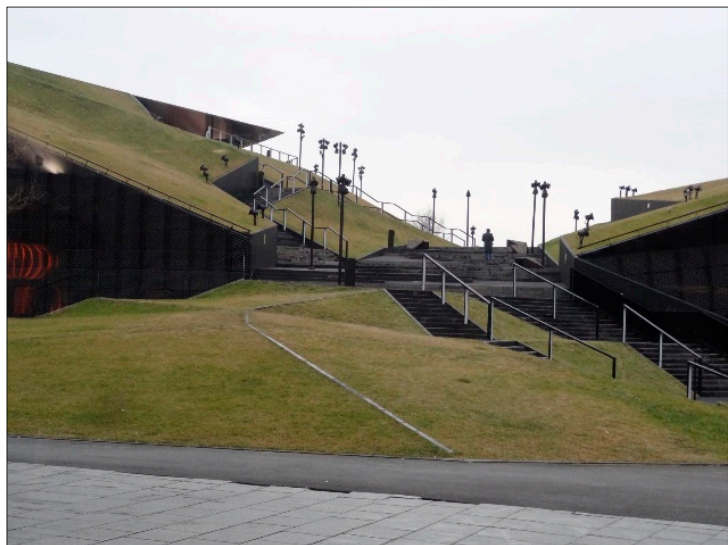

the use of urban green spaces in urbanized areas,

the inclusion of greenery as an element of revitalization of urban space,

integration of architecture and landscape,

combination of a building with the surrounding context,

architecture as part/extension of the landscape,

using elements of the natural environment so that they appear to be part of architecture,

compatibility of buildings and gardens,

permeation of the inside with the outside,

interaction from inside to outside and vice versa

ensuring a satisfactory view from the window,

the use of forms which reflect the contours of the landscape,

the use of symbolism connected with nature as a way of integrating architecture into the cultural and nature context,

camouflage as aesthetic sustainability,

integration of architecture and greenery (green roofing, grass roof),

the use of ecological natural earth colors,

designing scenic and recreational paths and terraces,

connecting functionality with processes taking place in nature, similar to human behaviors

(looking for shelter and a sense of security, searching for contact with nature, escape from the city noise, seeking peace and balance of mind, searching for sensations, looking for colors of nature). 
Table 3. Cont.

No. Picture

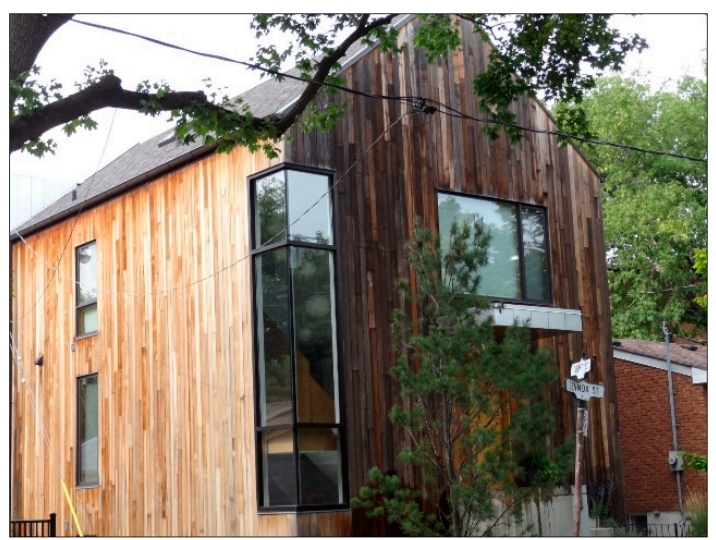

integration of architecture and landscape,

obtaining native materials from the landscape,

combination of environmentally-friendly technology, saving natural resources and aesthetic value,

harvesting indigenous materials (e.g., using native wood),

the use of recycled materials (recycled wood)

the use of a large amount of wood in the finishing of façade,

the use of glazing ensuring effective illumination with natural light,

integration of architecture and greenery

connecting functionality with processes taking place in nature, similar to human behaviors

(searching for contact with nature, escape from the city noise, seeking peace and balance of mind looking for colors of nature).

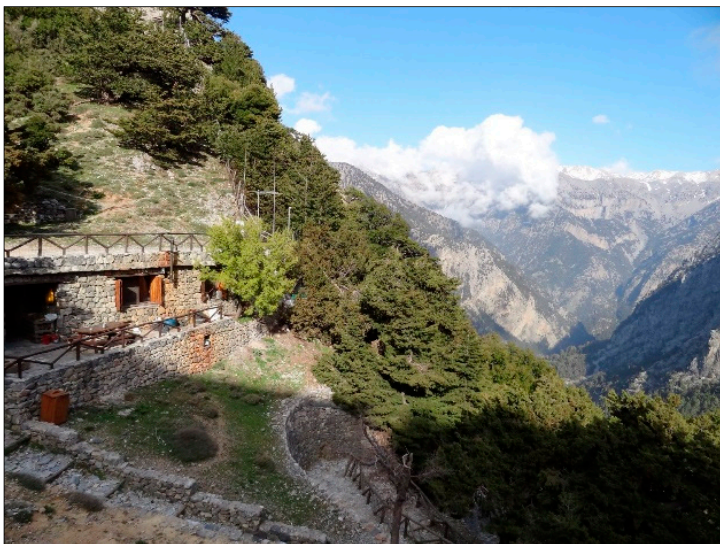

integration of architecture and landscape,

combination of a building with the surrounding context,

using elements of the natural environment so that they appear to be part of architecture,

the use of forms which reflect the contours of the landscape,

the use of symbolism connected with nature as a way of integrating architecture into the cultural and nature context,

camouflage as aesthetic sustainability,

obtaining native materials from the landscape,

harvesting indigenous materials (e.g., using native stone, wood),

the use of ecological natural earth colors,

integration of architecture and greenery,

ensuring a satisfactory view from the window,

designing scenic and recreational paths and terraces,

connecting functionality with processes taking place in nature, similar to human behaviors

(looking for shelter and a sense of security, searching for contact with nature, escape from the city noise, seeking peace and balance of mind, searching for sensations). 
Table 3. Cont.

No.

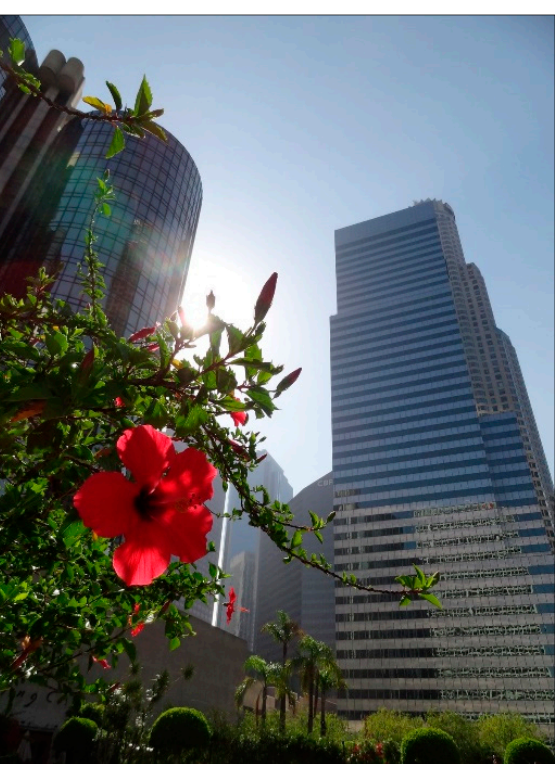

nature as a source of associations and inspirations in architecture,

camouflage as aesthetic sustainability (optical illusions, mirror reflections, using false patterns,

using the static motion in the surfacing screens, the shapes of camouflage within mimicry,

the use of green space in high-rise buildings,

the use of urban green spaces in highly urbanized areas,

compatibility of buildings and gardens,

the inclusion of floral elements in architecture,

integration of architecture and greenery,

ensuring a satisfactory view from the window

designing scenic and recreational terraces,

connecting functionality with processes taking place in nature, similar to human behaviors

(escape from the city noise, searching for contact with nature, looking for color, seeking peace and

balance of mind, searching for sensations).

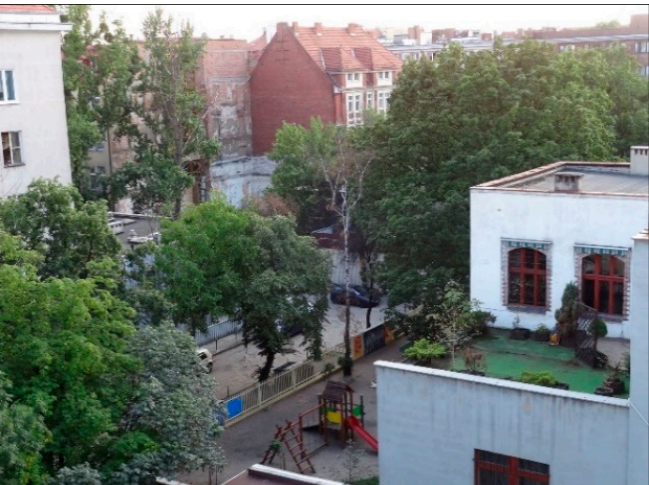

the use of urban green spaces in urbanized areas,

the inclusion of greenery as an element of revitalization of historical urban space,

compatibility of buildings and gardens,

ensuring a satisfactory view from the window

designing scenic and recreational paths and terraces,

camouflage as aesthetic sustainability (green walls, green roofs as a camouflage for aging

neglected architecture),

arranging internal intimate green squares equipped with small architecture and playgrounds

for children,

- connecting functionality with processes taking place in nature, similar to human behaviors

(looking for shelter and a sense of security, searching for contact with nature, escape from the city noise, seeking peace and balance of mind, looking for colors of nature). 
The image chosen by students as the most inspiring to take up "green architecture" themes and encouraging eco-design indicates that a velvety, meadow, herbaceous landscape can be used simply to bring light and joy to otherwise rugged, hard urban landscapes [45].

The research additionally compared the projects made as part of the Interior design 2019/2020 and Interior design 2020/2021 courses, taking into account ecological criteria, which made it possible to check and confirm the purposefulness and effectiveness of the presentation covering the principles of shaping environmentally-friendly architecture, features of "green architecture" and biophilic design, as well as sustainable development in architecture (a lecture opening design classes), and a mid-course survey as a didactic method to encourage students to take up the topics of "green architecture" and ecological design.

The evaluation shows that $80 \%$ of students participating in the Interior design course 2020/2021 chose design topics in the scope of "green architecture" and applied the principles of shaping environmentally-friendly architecture and used clear elements of ecological and biophilic design in their projects. This is $60 \%$ more than in the previous year.

\section{Conclusions}

Our research showed the effectiveness and high quality of the courses tested, as well as the rationality of the assumptions adopted for their implementation. The adopted methodology may be used by other educators in applying the guidelines developed by the authors.

The introduction of design strategies in the field of deep ecology in architectural education will allow us to look at nature not as something outside, but it will allow us to learn that all life forms are its integral part and are of great value. This is connected with the application of the educational system already from the pre-school level in the place of residence (e.g., by means of ecovillages, urban housing eco-structures), up to adult education, with an emphasis on direct, practical academic education, and thanks to friluftsliv-education in wild nature and municipal ecological parks designed for this purpose. Introducing changes for a deeply ecological future should include bottom-up actions, even though it will be of global character. What we need is striving to be the driving force where one lives, to achieve a more bioregional development, where the interdependence between nature, culture, and people co-evolve in a lasting and longterm way.

The use of the innovative research and education methods turns out to be an effective way of teaching sustainable and responsible architectural design. It gives extensive opportunities to consider advanced, so-far unproven technological and material solutions at the stage of student design concepts implemented as part of courses conducted by experienced architects who are academic teachers and researchers. It enables insightful observations and analyzes of the advantages and disadvantages of the adopted design assumptions and considered design solutions in the context of future implementations. This is done without any financial loss or negative user experience.

Intensive research and design cooperation between students and teachers in architectural faculties is a way to fulfill dreams of living in a harmonious relationship between users, buildings, and the natural environment. It was noticed that only the method of project cooperation, where both the student and the tutor feel responsible for the entire project process and its effects, may bring benefits in the future. Not only the transfer of knowledge about ecological architecture, but most of all reliable cooperation, can encourage students to adopt the idea of sustainable and responsible design into practical activities.

In addition to the conclusions of this work, an attempt was made to solve the problem of combining the necessary teaching and interdisciplinary research at universities of architecture, indicating the research through design (RTD) methodology as an effective method for real innovations in ecological and sustainable design. RTD method involves the inclusion of design activities in the research process and the use of design to acquire new quality knowledge, including knowledge about sustainable development. The RTD 
methodology can be helpful in discovering completely new solutions and introducing innovations in all areas of design, including architecture and interior design. Moreover, it can change the nature of everyday contact with technology and reduce the negative effects of digitizing life. By creating prototypes, patterns, sample projects, and unfinished products, it is possible to explore potential opportunities and innovations without large and risky investments [46]. For this reason, the RTD method could be extremely useful and effective in the area of teaching architectural design. Innovative design solutions focused on sustainable development in architecture can be recognized, analyzed, and verified already at the stage of student projects.

The RTD method can be used as a clear and effective teaching strategy for architectural design. The RTD method is productive in design education as it keeps students and teachers in a continuous loop of cognitive, creative, and reflection action, and emphasizes the value of theoretical concepts in understanding practice [47]. Theoretical concepts developed in design courses become a resource of knowledge and skills from which students can draw preparation for design practice, resulting from an understanding of the need to integrate theory and practice in architectural design.

Author Contributions: Conceptualization, E.C. and A.J.; methodology, E.C. and A.J.; validation, E.C. and A.J.; formal analysis, E.C. and A.J.; investigation, E.C. and A.J.; resources, E.C. and A.J.; data curation, E.C. and A.J.; writing-original draft preparation, E.C. and A.J.; writing—review and editing, E.C. and A.J.; visualization, A.J.; supervision, E.C. and A.J.; project administration, E.C. and A.J. All authors have read and agreed to the published version of the manuscript.

Funding: This research received no external funding.

Institutional Review Board Statement: Not applicable.

Informed Consent Statement: Not applicable.

Data Availability Statement: No applicable.

Acknowledgments: Authors would like to express sincere thanks to Everyone who contributed to this work, and in particular the Students who took part in the survey.

Conflicts of Interest: The authors declare no conflict of interest.

\section{References}

1. Alkaher, I.; Avissar, I. Assessing the impact of a program designed to develop sustainability leadership amongst staff members in higher education institutes: A case study from a community of practice perspective. Environ. Educ. Res. 2018, 24, 492-520. [CrossRef]

2. Ashford, N.A. Major Challenges to Education for Sustainable Development: Can the Current Nature of Institutions of Higher Education Hope to Educate the Change Agents Needed for Sustainable Development? In Proceedings of the 2010 ERSCP and EMU Conference on Knowledge Collaboration and Learning for Sustainable Development, Delft, The Netherlands, 25-29 October 2010.

3. Ashour, A. Design responsibility and sustainability in education. Int. J. Des. Nat. Ecodyn. 2020, 15, 129-133. [CrossRef]

4. Kulasiewicz, J. Głęboka ekologia Arne Næssa; Pracownia na Rzecz Wszystkich Istot: Bielsko-Biała, Poland, 1993.

5. Næss, A. Life's Philosophy, Reason and Feeling in Deeper World; University of Georgia Press: Ateny, Greece, 2002.

6. Abram, D. Ekologia głębi. Dzikie Życie 2011, 7, 25-26. Available online: http://pracownia.org.pl/dzikie-zycie-numeryarchiwalne, 2306, article, 5348 (accessed on 12 July 2021).

7. Næss, A. Livsfilosofi. In Et Personling Bidrag om Følelser og Fornuft; Universitetsforlaget: Oslo, Norway, 1998.

8. Devall, B.G.; Sessions, G. Ekologia Głęboka. Żyć w Przekonaniu, że Natura Coś Znaczy; Pusty Obłok: Warszawa, Poland, 1994.

9. Fox, W. Transpersonal ecology and the varietes of identification. Trumpeter 1991, 8, 3-5.

10. Jaglarz, A. Sustainable development in the concepts of modern bathrooms. Procedia Manuf. 2015, 3, 1638-1645. [CrossRef]

11. Ragheb, A.; El-Shimy, H.; Ragheb, G. Green architecture: A concept of sustainability. Procedia Soc. Behav. Sci. 2016, 216, 778-787. [CrossRef]

12. Stamm, A. Forty Years after the Imperative of Responsibility-Ethics of Technology Choice in Times of Eroding Planetary Boundaries. The German Development Institute/Deutsches Institut für Entwicklungspolitik (DIE) within the Framework of the Bonn Alliance for Sustainability Research. 2019. Available online: https:/ / www.die-gdi.de/veranstaltungen/details/theimperative-of-responsibility-understanding-hans-jonas / (accessed on 22 June 2021). 
13. Feria, M.; Amado, M. Architectural design: Sustainability in the decision-making process. Buildings 2019, 9, 135. [CrossRef]

14. Oh, S. From an ecodesign guide to a sustainable design guide: Complementing social aspects of sustainable product design guidelines. Arch. Des. Res. 2017, 30, 47-64. [CrossRef]

15. Jaglarz, A. Development of the ecological bathroom ideas. In Proceedings of the 9th International Conference (UAHCI 2015), Los Angeles, CA, USA, 2-7 August 2015; Antona, M., Stephanidis, C., Eds.; Springer: Berlin/Heidelberg, Germany, 2015. [CrossRef]

16. O'Donnell, K. What do Building Massing and Orientation Have to do with Sustainability? 30 September 2018. Available online: https:/ / www.metabuild.io/en/what-do-building-massing-and-orientation-have-to-do-with-sustainability/ (accessed on 12 August 2021).

17. Esteves, A.; Esteves, M.J.; Mercado, M.V.; Barea, G.; Gelardi, D. Building shape that promotes sustainable architecture evaluation of the indicative factors and its relation with the construction costs. Archit. Res. 2018, 8, 111-122. [CrossRef]

18. D'Amico, B.; Pomponi, F. A compactness measure of sustainable building forms. R. Soc. Open Sci. 2019, 6, 181265. [CrossRef]

19. Jaglarz, A. New concepts in arrangement of living spaces for students. In Advances in Human Factors and Sustainable Infrastructure, Proceedings of the AHFE 2016 International Conference on Human Factors and Sustainable Infrastructure, Orlando, FL, USA, 27-31 July 2016; Charytonowicz, J., Ed.; Springer: Berlin/Heidelberg, Germany, 2016. [CrossRef]

20. Celadyn, M. Integrative design classes for environmental sustainability of interior architectural design. Sustainability 2020, 12, 7383. [CrossRef]

21. Dammarell, L.A. Residential biophilia: Creating a nature based home for better psychological health. Creat. Compon. 2019, 156. Available online: https:/ /lib.dr.iastate.edu/creativecomponents/156 (accessed on 25 May 2021).

22. Sherman, G.; Walkingstick, T.; Wallen, K.; Pelkki, M. Architect familiarity and perceptions surrounding sustainable design, LEED, and engineered wood products in Arkansas. J. Sustain. Archit. Civ. Eng. 2020, 27, 16-31. [CrossRef]

23. Cichowska, J. Natural building as an environment friendly solution. Infrastruct. Ecol. Rural. Areas 2019, 2, 67-77. [CrossRef]

24. Lucchi, E.; Delera, A.C. Enhancing the historic public social housing through a user-centered design-driven approach. Buildings 2020, 10, 159. [CrossRef]

25. Pons-Valladares, O.; Nikolic, J. Sustainable design, construction, refurbishment and restoration of architecture: A review. Sustainability 2020, 12, 9741. [CrossRef]

26. Fairs, M. Carbon Revolution. The Materials that Store Carbon and Help Reduce Greenhouse Gas Emissions. 27 June 2021. Available online: https:/ / www.dezeen.com/2021/06/27/carbon-negative-carbon-neutral-materials-roundup/ (accessed on 12 August 2021).

27. Wojciechowski, T. Ku Gospodarce O Obiegu Zamkniętym. 2017. Available online: http:/ /www.forum-dyrektorow.pl/zipy/mat, serock,2017/6,Ku, gospodarce,w,obiegu,zamknietym, Tomasz-Wojciechowski.pdf (accessed on 22 June 2021).

28. Haukeland, P.I. O głębi filozofii i radości życia. Dzikie Życie 2010, 9, 195. Available online: https://dzikiezycie.pl/archiwum/20 10/wrzesien-2010/o-glebi-filozofii-i-radosci-zycia-rozmowa-z-perem-ingvarem-haukelandem (accessed on 12 July 2021).

29. Cisek, E. Norweska Architektura I Rzeźba Wobec Natury; Oficyna Wydawnicza Politechniki Wrocławskiej: Wrocław, Poland, 2017.

30. Mayur, R. Ecovillages and Sustainable Communities; Findhorn Press: Forres, UK, 1995.

31. Jakubowski, K. Piękno nieoczywiste. Rola miejskich nieużytków w kształtowaniu nowej kategorii parków miejskich. Przestrz. I Forma 2015, 24, 145-162.

32. Molenda, T. Problematyka ochrony środowisk antropogenicznych w Polsce. J. Ecol. Health 2013, 17, 76-80.

33. Gronostajska, B.E.; Berbesz, A.M. Universal design in the education of architecture students. World Trans. Eng. Technol. Educ. 2020, 18, 3 .

34. Kaplan, R.; Kaplan, S. The Experience of Nature: A Psychological Perspective; Cambridge University Press: Cambridge, MA, USA, 1989.

35. Juniper, A. Wabi Sabi. Japońska Sztuka Dostrzegania Piękna w Przemijaniu; Sensus/Helion: Gliwice, Poland, 2018.

36. Wines, J. Zielona Architektura; Jodidio, P., Ed.; Taschen: Köln, Germany; TMCArt: Warszawa, Poland, 2000.

37. Oberti, I.; Plantamura, F. The inclusion of natural elements in building design: The role of green rating systems. Int. J. Sustain. Dev. Plan. 2017, 12, 217-226. [CrossRef]

38. Rashdan, W.; Ashour, A.F. Criteria for sustainable interior design solutions, the sustainable city XII. WIT Trans. Ecol. Environ. 2017, 223, 311-322. [CrossRef]

39. Sterkenberg, Z. Office Futures: The Office Design Trends of 2020. 2019. Available online: https://www.ambius.com (accessed on 12 October 2020).

40. Richter, D. Camouflage as aesthetic sustainability. Arch. Des. 2006, 76, 62-68. [CrossRef]

41. Mohamed, R.H. The challenge of camouflage in architecture as means of efficiency. In Proceedings of the 10th International Conference on Civil and Architecture Engineering, Cairo, Egypt, 27-29 May 2014.

42. Passive Daylighting Systems Could Transform the Architecture of Natural Light. Available online: https://hmcarchitects.com/ news / transforming-a-space-through-architectural-lighting-design-2019-01-31/ (accessed on 29 June 2021).

43. Jaglarz, A. The health role of smart home bathroom. Builder 2021, 3. [CrossRef]

44. Jablonska, J.; Czajka, R. CAD tools and computing in architectural and urban acoustics. Buildings 2021, 11, 235. [CrossRef] 
45. Carmona, M.; Tiesdell, S.; Heath, T.; Oc, T. Public Places-Urban. Spaces. The Dimension of Urban. Design; Routledge Taylor\&Francis Group: New York, NY, USA, 2010.

46. Sitarz, H. Nowa Metoda Na Prawdziwe Innowacje: Research through Design. 2019. Available online: https://mobeedick.com/ $\mathrm{pl} / \mathrm{blog} /$ nowa-metoda-na-prawdziwe-innowacje-research-through-design/ (accessed on 16 June 2021).

47. Hansen, N.B.; Halskov, K. Teaching interaction design by research through design. In Proceedings of the 30th Australian Conference on Computer-Human Interaction (OzCHI '18), Melbourne, Australia, 4-7 December 2018; Association for Computing Machinery: New York, NY, USA; pp. 421-431. [CrossRef] 